\title{
Research on the Incentive Mechanism of
}

\section{Organic Integration between Teaching and Scientific Research}

\author{
Zhao Haiyan \\ School of Heilongjiang Bayi Agricultural University \\ Da Qing,China \\ 1e-mail:zhy700724@sina.com
}

\author{
Yin Shi \\ School of Heilongjiang Bayi Agricultural University \\ Da Qing,China \\ e-mail: shyshi0314@163.com
}

\begin{abstract}
Coordinate in undergraduate teaching and the scientific research in our country gained fruitful results, but the quality of higher education still exist many problems, including heavy research light teaching phenomenon is one of the most important problem. The organic integration of teaching and research incentive mechanism to promote teacher's teaching and scientific research, balanced and sustainable development, effective incentive mechanism is undergraduate research-based teaching implementation, teachers use, excitation, yukon, one of the important ways to leave, is to realize the condition on the undergraduate course colleges and universities teaching and scientific research management standardization.Heavy scientific research light teaching major disadvantages that exist in the phenomenon of undergraduate course teaching in our country.Based on the status quo that,in China, every college pay more attention to scientific research than teaching, learning advanced incentive mechanism for teachers in undergraduate education from abroad, I'll propose incentive mechanism on the construction of establishing favorable teaching bodies on both teaching management and practice, to improve teaching effectiveness, incentive system in the classroom, and teachers' teaching enthusiasm and creativity. Promoting the coordinated development of teaching and scientific research.
\end{abstract}

Keywords-teaching;scientific research;incentive mechanism; higher education;reform

\footnotetext{
${ }^{1}$ Fund: Heilongjiang Provincial Department of Education 2013 education reform fund "Undergraduate Research Teaching Practice organic integration of teaching and research," the initial results.

Author: Zhao Haiyan (1970 -), female, Lanxi County, Heilongjiang Province, Professor, Doctor of Management, is mainly engaged in corporate finance risk research and rural financial problems.

Yin Shi (1988-), male, Hebei Chengde, assistant accountant, Master, research direction: Financial Management.
}

\section{INTRODUCTION}

In our undergraduate teaching and scientific research, we have obtained abundant accomplishment, but there are still many problems of higher education quality. The most important issue of it is light weight teaching. The major disadvantages in our undergraduate teaching is colleges pay more attention to scientific research than teaching. Incentive mechanism of organic integration between teaching and scientific research promotes Coordination and sustainable development of teaching and scientific research. Effective incentive mechanism is an important way for Teaching of undergraduate study to realise recruitment,employment, encouragement, education, retain ment of teachers, and it is also a prerequisite to realizing normal undergraduate education and the management of scientific research.

\section{ForEIGN TEACHERS INCENTIVE MECHANISM IN UNDERGRADUATE EDUCATION}

\section{A. United States}

Professor Tenure System.University of Wisconsin in the early 20th century implement this system. Tenure is a concise, objective and impartial procedures and standards, mainly including six steps: application, evaluation, voting, recommending, reviewing, examining and approving and feedback.American university professor tenure system is an effective system for the organic integration of teaching and scientific research, which not only ensure that teachers adhere to realistic and scientific attitude, treat academic studies seriously, and fully mobilize the enthusiasm of teachers, input more into the teaching, forming contentious situation, and can attract the best teachers, building good teacher staff.

Vocational Training Incentives.Ph.D.in American colleges and universities are generally in the basic conditions for teachers, so you do not like Chinese teacher qualifications Ph.D.study grants, focusing on research in American universities, while teaching is very concerned about the outcome of the evaluation of teachers, improve teacher training and practical skills, increase the actual teaching problem solving efforts, pay full attention to the process of teacher education.Through the exchange of 
teachers and teacher learning, teachers master the rules and methods of teaching, but also for young teachers systematic and professional track training.

\section{B. Japan}

In terms of teaching and scientific research, they encourage development of scientific research while strengthening healthy and rapid development in teaching, but still accounted for the majority of the research currently. In terms of attitude, teachers'attitude and degree of passion for teaching, a sense of responsibility as a teacher to students.On remuneration, the Japanese university teachers basic salary is basically determined by seniority. The duties and qualifications of university teachers determine the basic wage. Japanese universities is divided into two types: national public and private. Public school teachers in the country are treated with the standard of civil servants, and private salaries and wages of public school teachers are in balance. In welfare, the Japanese university teachers into the series as required can apply to join Freemasonry annuity. Under the existing system in Japan, after adding, medical and livelihood security have no relationship with the original work unit, and the entire insurance is undertaken by Freemasonry.

\section{The United Kingdom}

British university teachers'performance evaluation is divided into three aspects: accountability, employee motivation and career development purposes, in order to improve the teacher evaluation based on the efficiency of teaching and research. UK universities generally consider teaching and scientific research, but more concern about the ability of teachers'administrative services. Based on the above three areas, we can get a comprehensive and systemic assessment. Through the examination and evaluation of Teachers in universities and representatives from related fields, they can get a conclusion which is one of the bases that he or she will be continually employed, promoted, and changed payment.

In comprehensive view, Comprehensive view, foreign teachers incentive mechanism based on the organic integration of teaching and research is not simply rely on a source of information, instead of using several methods synthetically. From the point of incentive mechanism purpose, main is to support and encourage the coordinated development of teachers' teaching and scientific research ability, use all kinds of synergy incentives to mobilize different levels university teachers' initiative and creativity, to form a set of is all a, level and efficiency of incentive mechanism, make the university teachers gradually formed a kind of comprehensive teaching professional and advanced scientific research achievements. But despite foreign college teachers incentive mechanism is more perfect, foreign universities are more inclined to give priority to in order to research university development, according to the coordinated development of teaching and scientific research incentive mechanism also has certain potential utilitarian value orientation, teaching, scientific research and public service is the most important is still in research. Foreign colleges and universities, therefore, incentive mechanism, we should take its essence, to its dregs, at the same time we should based on the development of China's national conditions to fully take into account the reality of colleges and universities, according to the incentive system of colleges and universities of China, build the undergraduate course colleges and universities teaching and scientific research incentive mechanism of organic integration.

\section{BuILDING THE INCENTIVE MECHANISM OF TEACHING AND SCIENTIFIC RESEARCH}

\section{A. In the management of teaching}

In university management, according to the different situation, teachers in colleges and universities on the basis of different classification can be divided into many categories. The main factors influencing the university teachers classification are shown in table I.

TABLE I. CLASSIFICATION ON THE BASIS OF UNIVERSITY TEACHERS

\begin{tabular}{|c|c|}
\hline $\begin{array}{c}\text { Classification on the basis } \\
\text { of university teachers }\end{array}$ & The division of the category \\
\hline University education category & $\begin{array}{c}\text { Teaching university, research } \\
\text { university, research type } \\
\text { university, the university of } \\
\text { applied }\end{array}$ \\
\hline Job category & $\begin{array}{c}\text { Teaching is given priority to, } \\
\text { mainly research, teaching, } \\
\text { scientific research and heavy }\end{array}$ \\
\hline $\begin{array}{c}\text { Series of professional technical } \\
\text { position }\end{array}$ & $\begin{array}{c}\text { College teachers series, a series } \\
\text { of scientific research }\end{array}$ \\
\hline Specialized technical post \\
grades & $\begin{array}{c}\text { Is high, high, intermediate, and } \\
\text { associate }\end{array}$ \\
\hline University academic level & $\begin{array}{c}\text { Comprehensive university, } \\
\text { multidisciplinary university, } \\
\text { meet a kind of university }\end{array}$ \\
\hline The different stages of life & $\begin{array}{c}\text { Young, middle-aged and young, } \\
\text { middle-aged and old stage, old } \\
\text { age stage }\end{array}$ \\
\hline
\end{tabular}

University teachers in the process of hiring when signing a contract with the teacher and the degree of commitment to teachers and their efforts to the thing which is matching the conditions for teacher development school, the school and teachers commitment and motivation level corresponding output or effort degree, and to get the corresponding reward. Only when the school development goals consistent with the development of the teachers intend, incentives to achieve output. Thus the "Fig. 1" incentive process analysis of the research university.

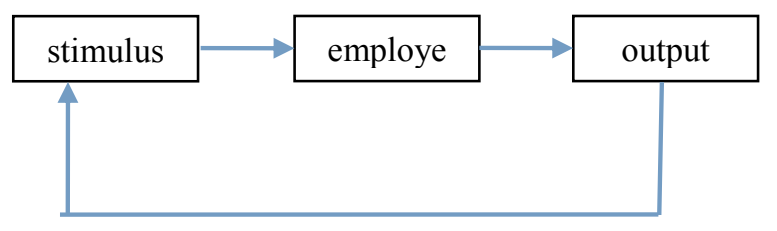

Figure 1. Research universities incentive mechanism process

At present, the college teachers incentive mechanism of the organic integration of teaching and research study rarely, generally based on personnel changes to restrict or encourage teachers, teacher's teaching and scientific research system of incentive mechanism is not perfect, 
restricting the enthusiasm of teachers' teaching and scientific research innovation, thus build the organic integration of teaching and research of incentive mechanism is very necessary.

Encourage teachers to teach and research

In the management of teaching, Chinese universities should establish a fund for research and innovation. Project funds can come from universities, community donations, and each school (department) financial support. Establishment of the fund not only improve university teaching mechanism, but also improve the teaching quality of teachers, and train teachers in teaching enthusiasm and through deep knowledge, teachers will learn the innovation of integration in teaching and scientific research. Prior to the implementation of teaching research and fund reformed, university teachers themselves need consider their own career planning as a reference to make career planning. Teachers'specific career planning are as follows: each according to hobbies, strengths, abilities and experience different aspects of integrated measurement, particularly based on individual psychological and physiological characteristics and career orientation, respectively, qualitative and quantitative analysis, by the comprehensive assessment and professional analysis, Finally, determine the optimal personal career development plan. According to teachers'different career planning, universities apply different incentives. As different teachers have different career planning, universities can make three teachers planning incentives, such as professor, researcher and professional leadership. For those who prefer a high level of education and teaching, innovative and practical in teaching, have professional development in potential, can follow assistant Lecturer Associate Professor Professor direction to motivate; teachers with capacity for research and innovation with higher innovation ability, and own a high level of scientific research, teaching weak can follow Assistant Researcher, Associate Professor, researcher direction to motivate; teachers with stronger coordination capacity for the organization, like the work of teachers and personnel, can follow the counselor, Secretary of the Youth League Committee, Head Incentive direction at all levels of leadership. Therefore, through teaching research and reform fund, they establish teaching, scientific research, administration to develop incentive mechanism, to fully tap university talent, and to deeply conduct teaching and research.

Strengthen training for teachers on teaching research

In terms of the quality of teaching in college, according to teachers' needs for their own career planning, our colleges and universities can strengthen the training on technical research and methods of teaching. By learning different methods of teaching improving teaching strategies, fully tapping the talent of teaching, they can make a comprehensive development of scientific research and leadership. In training incentives, according to diferfent categories, objects need different levels of training, and individual needs, teachers choose the content and methods of training in autonomous training time. Teachers should use teaching organic integration efforts which provides training on improving teaching standards, training, learning opportunities for themselves. Colleges and universities in China should speed up the training of teachers' work of scientific research and information construction, conduct diversification of training, make full use of university resources to create opportunities of self training and self learning for teachers. Universities need to send more teachers of research and teaching to abroad for study, consider wiping, international teaching methods and techniques of teaching, and communicate with them, in order to improve teaching methods, quality of teachers. University teachers need to achieve self-development and in-depth study of teaching.

\section{B. In the teaching practice}

\section{1) Improve teachers' job titles}

For universities, firstly, they should enhance the system to improve teachers' titles, and put teaching quality and the evaluation of incorporate feedback into the system; Secondly, universities can provide a ladder corresponding instructional technology ladder with scientific research, make instructional teachers more satisfied with the same titles they have obtained, and inspire teachers' teaching enthusiasm; Thirdly, universities support and encourage teachers to conduct research teaching seminars, lectures, etc. outside. Through academic groups, organizations outside,teachers will struggle to get relevant results in teacher. Finally, according to " Employment for separation " system for enhancing teachers' titles, teaching teachers who meet certain age and the appropriate teaching titles, will be set a quota post according to the evaluation of teaching and teaching methods. Such incentives can not only make teachers improve the quality of teaching and scientific research capacity, but only playe an important role in guiding the main focus of the teachers.

\section{2) Improve teaching enthusiasm and creativity}

Considering teaching achievement awards,based on the salary of university teachers, according to the Ministry of Education, Division of Personnel, " Higher income distribution and the basic ideas of reform, " the survey shows that college teachers are not satisfied or very satisfied to their income with the accounting for $66.7 \%$, and basic satisfied, satisfied or very satisfied with the accounting for only $30.8 \%$. In the case of despise teaching and paying more attention to scientific research, the teaching achievement awards should not be satisfied. Therefore, in deepening the reform of teaching and scientific research, we should focus on improving the teaching achievement award, establishing classroom teaching allowance system, optimizing incentives and subsidies of teacher, ensuring the project on the basis of wages to job, adjusting teaching achievement and allowances structure based on post, performance, market to ensure the fairness of incentives and subsidies allocated.

\section{CONCLUSION}

For colleges and universities, especially in the inside and outside the classroom, teachers to guide undergraduate students, and guidance of reward consideration, can be based on actual cost $120 \%$ of the subsidies as a guide for undergraduate students. Such not only increase the income of teachers, meet the hygiene factors, teachers, in the spirit of undergraduate results give affirmation, under the guidance of teachers play a leading role, teachers in colleges and universities undergraduate course guide practice. Therefore, in terms of basic pay, 
can we consider post salary, pay wages, job subsidies, local subsidies, etc. Mainly according to the decision in accordance with the relevant national standards and school system, the universities should fully control in the teaching, strengthen management, promote the development of teaching; Here in benefits, incentive mechanism, this paper discusses mainly the teaching mainly divides into the campus allowance and allowance. Campus subsidies mainly consider the teacher teaching achievement award, classroom teaching allowance, etc., teaching achievement awards including teaching can improve the innovation of teaching methods, and the innovation of educational technology, etc., classroom benefits including, classroom students a reward, in order to promote the quality of classroom teaching cost, etc. Off-campus allowance, colleges and universities should be more emphasis on off-campus teaching incentive effect, mainly by the external post allowance, external direct allowance, special allowance, etc.

The rapid development of undergraduate education in our country, undertaking the important task of training senior talents. The coordinated development of teaching and research, explore the research of the value of scientific research in teaching, use of scientific research achievements in scientific research, so that colleges and universities can effectively cultivate specialized talents of science and technology, optimize the structure of university development, accelerate the development of modernization. The improvement of teaching quality in colleges and universities is the necessary conditions for their own development, education, power, of itself, is the necessary guarantee to win in the competition of colleges and universities. College teachers to improve the teaching quality in colleges and universities and development played an important positive role. So make the organic integration of teaching and research incentive mechanism is to effectively motivate teachers to coordinate the relationship between, fully arouse the enthusiasm of the teaching, improving teaching quality in colleges and universities, is of great significance.

\section{REFERENCES}

[1] How journal rankings can suppress interdisciplinary research: A comparison between innovation studies and business \& management I Rafols, L Leydesdorff, A O'Hare, P Nightingale.Research Policy, 2012 -

[2] Teaching and Research: Perspectives from Portugal.R Santiago, SB Sousa, T Carvalho.Teaching and Research.2014

[3] DBER and STEM education reform: Are we up to the challenge?V Talanquer - Journal of Research in Science Teaching, 2014

[4] Role of Technical Scientific Research Education in Sustainable Development and Conservation in Sudan

[5] AM Omer - Journal of Educational and Social Research, 2011

[6] Mentoring Graduate Students in Research and Teaching by Utilizing Research as a Template.CC Knutson, MN Jackson Jr, M Beekman... - Journal of Chemical, 2014

[7] Application Research on the Multimedia Technology in Teaching Reform.L Rui-ji - JDCTA: International Journal of Digital Content , 2012

[8] Research on Multi-Layered Modular Experimental Teaching System of the Public Management Specialties.M Song - Applied Mechanics and Materials, 2012

[9] Marsh,H.,Hattie,J.The relation between research productivity and teaching effectiveness: Complementary, antagonistic, or independent constructs?. J. Higher Educ,2002(10)185-224

[10] Lucie Morin,Stephane Renaud.Participation in Corporate University Training:Its Effect on Individual Job Performance. Canadian Journal of Administrative Sciences,2004(9)162-199

[11] Devi.The ImPaet of Ineentive Systems on Faeulty Behavior.Change2000(3)56-59

[12] http://www.moe.gov.cn/publicfiles/business/htmlfiles/moe/moe_3 07/200505/7444.html

[13] http://www.moe.gov.cn/publicfiles/business/htmlfiles/moe/A01_zc wj/201008/xxgk_93785.html

[14] http://www.moe.gov.cn/publicfiles/business/htmlfiles/moe/s6342/ 201109/xxgk_125202.html

[15] Maslow, A. H. A theory of human motivation[J]. Psychological Review, 1943(4): 370-396.

[16] Herzberg, Frederick (1959), The Motivation to Work, New York: John Wiley and Sons, ISBN 978-1-56000-634-3

[17] Alderfer, Clayton P., An Empirical Test of a New Theory of Human Needs $[\mathrm{J}]$. Organizational Behaviour and Human Performance, 1969(5)142-175.

[18] McClelland, David C. Managing motivation to expand human freedom[J]. American Psychologist, 1978(3) :201-210.

[19] Vroom V H. Work and motivation. New York: Wiley, 1964(10):331-332. 